\title{
Comparative Immunological Recognition of Proteins from New Guinea " $C$ " Dengue Virus Type 2 Prototype and from a Dengue Virus Type 2 Strain Isolated in the State of Rio de Janeiro, Brazil

\author{
Luzia M de C Côrtes*, Ortrud M Barth, Josery R Pantoja*, Carlos R Alves*/+
}

\author{
Departamento de Virologia *Departamento de Bioquímica e Biologia Molecular, Instituto Oswaldo Cruz-Fiocruz, \\ Av. Brasil 4365, 21045-900 Rio de Janeiro, RJ Brasil
}

The protein profiles of the New Guinea "C" dengue virus type 2 (DENV-2)prototype and those of a Brazilian DENV-2 isolated in the State of Rio de Janeiro in 1995 were compared. SDS-PAGE analysis showed that the virus from Rio de Janeiro expresses NS5 (93.0 kDa), NS3 (66.8 kDa) E (62.4 kDa) and NS1 (41.2 kDa) proteins differently from the New Guinea " $C$ " virus. The immunoblot revealed specificity and antigenicity for the NS3 protein from DENV-2 Rio de Janeiro mainly in primary infections, convalescent cases, and in secondary infections in both cases and only antigenicity for E and NS1 proteins for both viruses in primary and secondary infections.

Key words: Flavivirus - dengue virus type 2 proteins - antigenicity - Rio de Janeiro - Brazil

Dengue viruses (DENV) belong to the family Flaviviridae, genus Flavivirus, and occur as four antigenically related but distinct serotypes designated DENV-1, 2, 3 and 4 (Heinz et al. 2000). Infection with these serotypes causes a spectrum of illness ranging from a mild nonspecific febrile disease to severe and fatal haemorrhagic forms called dengue haemorrhagic fever/ dengue shock syndrome (DHF/DSS). The infection is prevalent in over 100 tropical and sub-tropical countries, threatening the lives of 2,5 thousand million people. It is estimated that 100 million cases of dengue fever (DF) and 250,000 cases of DHF occur annually (WHO 1997). The regions in which dengue virus infections are a serious health problem have been expanded mainly in the American continent where an increasing number of DHF/DSS cases have been observed. The reintroduction of DENV in Brazil in the 1980s was a result of the reinfestation with the vector Aedes aegypti in the country, in the late 1970s. In Brazil, a total of 1,832,371 cases of DF and 983 of DHF/ DSS have been reported since 1986 when dengue infection became a national health problem resulting from DENV-1 and since 1990 from DENV-2 epidemic infections which occurred in 24 out of 26 states in Brazilian states (Nogueira et al. 2001).

All serotypes of dengue virus have a genome that consists of a single strand of RNA encoding the structural proteins: capsid (C), pre membrane/membrane (prM/ $\mathrm{M})$ and envelope (E) and for non structural (NS) proteins:

This investigation received financial support from the Conselho Nacional de Desenvolvimento Científico e Tecnológico (CNPq). ${ }^{+}$Corresponding author. Fax: +55-21-2590.3495. E-mail: calves@ioc.fiocruz.br

Received 12 July 2002

Accepted 7 March 2003
NS1, NS2a, NS2b, NS3, NS4a, NS4b and NS5 (Rice et al. 1985). The infections result in the development of antibodies to viral structural proteins, although nonstructural proteins have also been described eliciting antibody responses (Chudboonchant et al. 1991, Se-Thoe et al. 1999, Shu et al. 2000). The dengue virus infections in humans induces a rapid and potent antibody response that is easily measured by many serological tests. However, the qualitative antibody response to DENV has not been widely studied and the distinct antigenicity within the same serotype is possible because genome differences occur in various population groups and may influence the immune response of the patients (Guzman et al. 1984).

The objective of this study was to analyze the protein profiles of the New Guinea "C" DENV-2 prototype (DENV$2 \mathrm{NG}$ ) and those of a Brazilian DENV-2 strain (DENV-2 RJ) isolated in the State of Rio de Janeiro in 1995. We comparatively evaluated the immunological recognition of the viral proteins using human sera in an immunoblot assay and discussed the serological findings. Additionally, the DENV-2 protein profiles were appraised by analysis of infected cells metabolically labeled with $\left[{ }^{35} \mathrm{~S}\right]$-methionine (Corner \& Ng 1987).

During the study, DENV-2 strains were grown in the Aedes albopictus clone C6/36 cell line (Igarashi 1978). The virus samples obtained from sucrose gradients (Smith et al. 1970) were solubilized in lysis buffer (10 mM Tris-HCl pH 6.8 containing 1\% 3-([3-cholamidopropyl] dimethylammonio)-1-propanesulfonate, $1 \mathrm{mM}$ phenylmethylsulfonyl fluoride, $1 \mathrm{mM}$ N-tosyl-L-phenylalanine chloromethyl ketone, $10 \mu \mathrm{M}$ trans-Epoxysuccinyl-Lleucylamido-(4-guanidino) butane and $1 \mathrm{mM} \mathrm{1,10-}$ phenanthroline). The samples were treated with sample buffer (v/v; 80 mM Tris-HCl pH 6.8, 2\% Sodium Dodecyl Sulfate (SDS), $12 \%$ glycerol, $5 \% \beta$-mercaptoethanol and $0.05 \%$ bromophenol blue) and proteins profile resolved in SDS polyacrylamide gel electrophoresis (SDS-PAGE), ac- 
cording to Laemmli (1970). After electrophoresis of the proteins, the immunoblots were produced as previously described by Towbin et al. (1979) and the immune complexes were visualized using secondary antisera conjugated to horseradish peroxidase.

Sera from 30 patients used in this study, representing patients having primary dengue infection $(\mathrm{n}=16)$ and secondary dengue infection $(\mathrm{n}=14)$ were obtained during the epidemics in the State of Rio de Janeiro between 1995 and 2000. The samples of the acute and convalescent cases were grouped according to the serologic criteria set by WHO (1986). DENV-2 virus isolated from a serum sample in the clone $\mathrm{C} 6 / 36$ and was typed by the indirect fluorescent antibody test using serotype-specific monoclonal antibodies (Gubler et al. 1984). The sera of the patients were classified in primary (titers $\leq 1: 160$ ) and secondary (titers $\geq 1: 160$ ) infections according to G-ELISA titers (Miagostovich et al. 1999). ELISA's detect IgM and $\operatorname{IgG}$ in the serum and thus are able to distinguish primary infection (IgM elevated early, IgG later to low titer) from secondary infection (IgG elevated early to higher titer than IgM).

An advantage of the combination of SDS-PAGE and immunoblotting is the characterization of antibodies to specific dengue proteins. Such a procedure may be used for both qualitative and quantitative analyses of antibody responses towards viral structural proteins as well as the nonstructural proteins already described (Chang 1997). The SDS-PAGE analysis confirmed that the two virus strains may present different protein profiles (Figure). These data were confirmed by additional experiments using DENV-2 RJ and DENV-2 NG proteins labeled with $\left[{ }^{35} \mathrm{~S}\right]$-methionine, indicating that DENV-2 RJ expresses NS5 (93.0 kDa), NS3 (66.8 kDa) E (62.4 kDa) and NS1 (41.2 $\mathrm{kDa}$ ) proteins differently from the New Guinea " $\mathrm{C}$ " virus strain (data not shown).

The antibody recognition profiles of the different protein components were demonstrated by the immunological recognition of DENV-2 RJ and DENV-2 NG proteins using human serum samples. The immunoblotting graphical profile of all sera assayed against the two isolated viruses is presented in the Figure. It was observed that reactivity of antisera was predominant in the range corresponding to $71.7 \mathrm{kDa}$ and $36.5 \mathrm{kDa}$ proteins of DENV-2 RJ and DENV-2 NG viruses, when compared to the standard molecular mass markes used (Figure). Quantitative recognition of protein by human sera was stronger in preparations of the DENV-2 RJ virus. Specific recognition was detected for proteins NS3 $(71.1-66.0 \mathrm{kDa}), \mathrm{E}(62.4-53.0 \mathrm{kDa})$, NS1 (51.9-40.0 kDa), C-prM (38.3-32.1kDa) and NS4b (27.2$26.3 \mathrm{kDa}$ ). Interestingly, the sera of the patients with low serological IgG titers $(<1: 40)$ recognized several of the proteins, such as: $71.7 \mathrm{kDa}, 66.0 \mathrm{kDa}, 63.1 \mathrm{kDa}, 57.0 \mathrm{kDa}$, $56.4 \mathrm{kDa}, 54.3 \mathrm{kDa}, 51.4 \mathrm{kDa}, 49.2 \mathrm{kDa}, 47.0 \mathrm{kDa}$ and 46.6 $\mathrm{kDa}$. The specificity of the reaction was confirmed when we included samples of serum (five) of individuals without clinical history of the illness affection and whose serological and isolation tests of the virus were negatives. Thus, no protein band was detected when these sera were used (1/100) against proteins from DENV-2 RJ and DENV$2 \mathrm{NG}$, in the immunoblotting assays.
The results suggest that DENV-2 RJ proteins had a higher immunological recognition when compared to DENV-2 NG proteins (Figure and Table). We observed that the protein molecular mass is not exactly the same as described by other authors (Se-Thoe et al. 1999). In this context, it is important to have in mind that the heterogeneity in the molecular mass of those proteins could be explained by both viral and host proteases that may be involved in processing the flavivirus proteins (Biedryzcka et al. 1987). Moreover, it is known that some flavivirus proteins reach different migration levels in SDS gels considering the intracellular and virion-associated forms (Wright \& Westaway 1977, Svitkin et al. 1984).
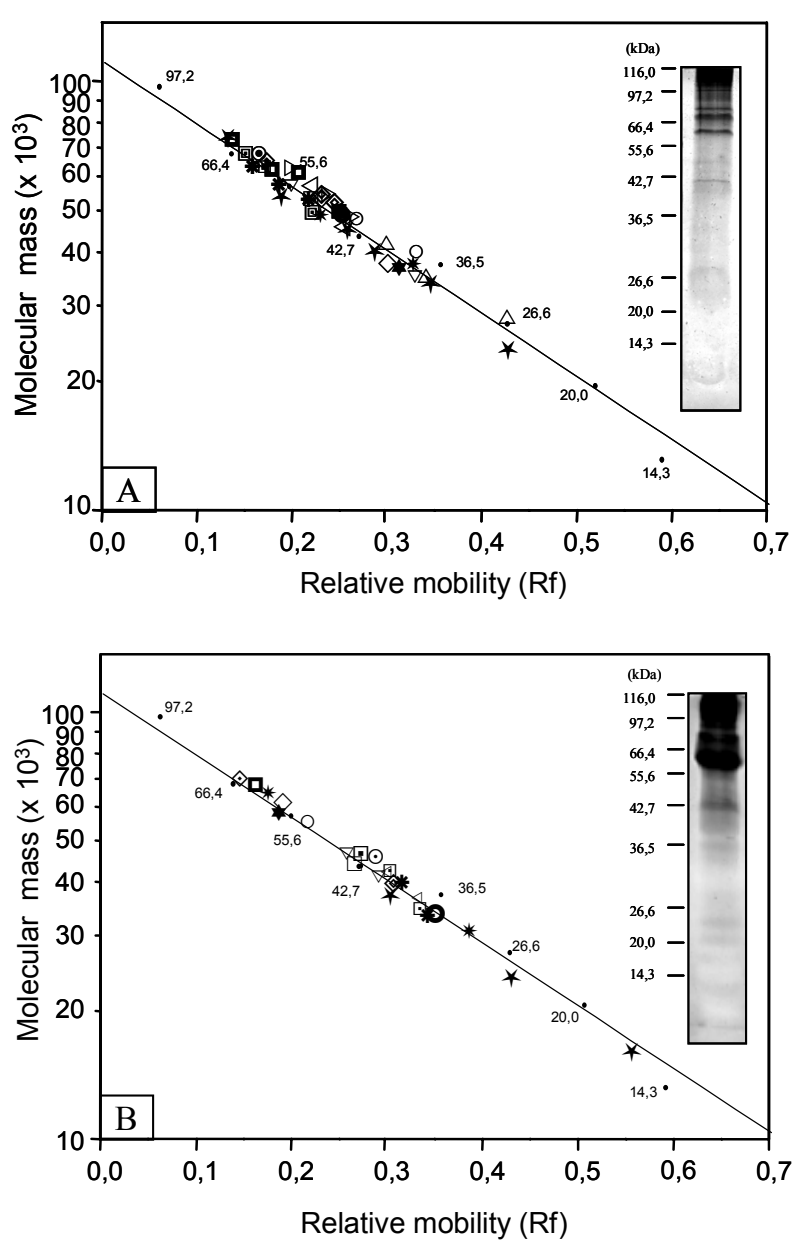

Graphical representation of the immunoblotting assay. Approximately $60 \mu \mathrm{g}$ of proteins were solubilized in sample buffer $(\mathrm{v} / \mathrm{v})$ and SDS-PAGE resolved proteins were transferred to nitrocellulose paper. Nitrocellulose-bound proteins were incubated with human sera (1:100) and specific antigens were revealed with peroxidase-conjugated anti-human immunoglobulins, and incubation with $\mathrm{H}_{2} \mathrm{O}_{2}$ and 3,3'-diaminobenzidine. The inserts show samples of the RJ (A) and NG (B) Den-2 virus protein profiles analyzed after sucrose gradient purification and resolved in $12.5 \%$ SDS-PAGE followed by silver staining. The molecular mass values of standard proteins are indicated on the left. The curve shown was obtained by blotting the log of the molecular mass $\left(x 10^{3}\right)$ of the broad range standard versus the relative mobility (Rf). Each symbol used represents a different human serum sample analyzed. 
TABLE

Proteins from dengue virus type 2 RJ and dengue virus type 2 NG recognized by sera from primary and secondary dengue infections

\begin{tabular}{|c|c|c|c|c|c|}
\hline \multirow[b]{3}{*}{ Infection } & \multicolumn{5}{|c|}{ Virus proteins } \\
\hline & $\mathrm{NS} 3^{a}$ & $\mathrm{E}^{b}$ & $\mathrm{NS} 1^{c}$ & C-prM ${ }^{d}$ & $\mathrm{NS} 4 \mathrm{~b}^{e}$ \\
\hline & $\mathrm{RJ} / \mathrm{NG}$ & $\mathrm{RJ} / \mathrm{NG}$ & $\mathrm{RJ} / \mathrm{NG}$ & $\mathrm{RJ} / \mathrm{NG}$ & $\mathrm{RJ} / \mathrm{NG}$ \\
\hline Primary & $37 / 18$ & $43 / 18$ & $43 / 25$ & $6 / 18$ & $0 / 0$ \\
\hline Acute cases $(\mathrm{n}=11)$ & $12 / 18$ & $31 / 12$ & $43 / 25$ & $6 / 18$ & $0 / 0$ \\
\hline Convalescent cases $(n=5)$ & $25 / 0$ & $12 / 6$ & $0 / 0$ & $0 / 0$ & $0 / 0$ \\
\hline Secondary & $70 / 0$ & $40 / 28$ & $50 / 50$ & $28 / 21$ & $14 / 7$ \\
\hline Acute cases $(n=7)$ & $35 / 0$ & $20 / 14$ & $0 / 15$ & $7 / 0$ & $0 / 0$ \\
\hline Convalescent cases $(n=7)$ & $35 / 0$ & $20 / 14$ & $50 / 35$ & $21 / 21$ & $14 / 7$ \\
\hline
\end{tabular}

Nonstructural proteins - $a$ : NS3; $c$ : NS1; $e$ : NS4b. Structural proteins $-b$ : E; $d$ : C-prM. The sera from Rio de Janeiro patients were assayed with Rio de Janeiro (RJ) and New Guinea "C" prototype (NG) virus samples. The data represent the percentage of primary $(\mathrm{n}=16)$ and secondary $(\mathrm{n}=14)$ human sera that recognized DENV-2 RJ and DENV-2 NG proteins.

The major protein bands detected by human sera were analyzed according to infection type (Table). The sera detected mainly the structural $\mathrm{E}$ and $\mathrm{C}$-prM proteins and nonstructural NS3 and NS1 proteins from DENV-2 RJ and DENV-2 NG. The results showed that sera from primary infection patients with low $\operatorname{IgG}$ antibodies titers $(<1: 40)$ had higher immunological recognition for $\mathrm{E}$ and NS1 proteins of the DENV-2 RJ than for DENV-2 NG proteins. Curiously, in primary infections, independent of the type of viral antigen, serum samples did not recognize the NS4b proteins. Convalescent cases sera from secondary infection that produced significant quantities of IgG isotype had a marked recognition of the NS3, E, NS1 and NS4b proteins of the DENV-2 RJ and low recognition of these proteins from DENV-2 NG. This affirmative was not confirmed for NS1 proteins from DENV-2 NG, in our experimental conditions. A more limited response was observed with C-prM in primary and secondary infections and with NS4b in secondary infection, independent of virus samples (Table).

Observations of the Churdboonchart et al. (1991) indicate that sera from primary dengue cases collected during the convalescent cases detect NS3, E and NS5 protein. The results of this work suggest that DENV-2 RJ NS3 and E proteins can be recognized in the acute and convalescent cases of primary and secondary infections (Table). Moreover, secondary dengue infected patients always demonstrated IgG antibodies to E proteins in sera collected during the acute case, among other proteins (NS1, NS3, NS5 and C) in sera obtained from convalescent cases (Churdboonchart et al. 1991). In contrast, primary or secondary infections sera, in our experimental conditions, did not detect the NS5 protein.

We identify also that the NS1 proteins from DENV-2 $\mathrm{RJ}$ may be detected in the acute cases of primary infection, and in the convalescent cases of secondary infection. This data agrees with those of another study, where anti-dengue NS1 antibodies were demonstrated in higher frequencies in acute case serum samples from secondary infections in Indonesia than in those from Puerto Rico (Kuno et al. 1990).
Our results revealed the specificity and antigenicity of the NS3 protein from DENV-2 RJ mainly in primary infections, convalescent cases, and in secondary infections in both cases and only antigenicity of the E and NS1 proteins from both viruses in primary and secondary infections. Recent studies indicate that anti-NS1 and -NS3 antibodies are detected mainly in secondary infections while those anti-E and anti-NS3 antibodies are detected in both primary and secondary infections (Valdés et al. 2000). This fact indicates that virus proteins derived from strains of the viruses that are causing disease in a given area are more useful for dengue virus diagnostic in that endemic area. Thus, it is possible that some of these proteins may be used to monitor the disease in humans risk areas, if the prevalence of the antigenicity of these proteins and absence of cross reaction with other flaviviruses are confirmed. Further studies are necessary to elucidate these questions.

\section{ACKNOWLEDGEMENTS}

To the Laboratório de Produção e Processamento de Imagens, IOC-Fiocruz, for expertise in photographic work; to Dr RMR Nogueira and Dr MP Miagostovich (Laboratório de Flavivírus, Departamento de Virologia, IOC-Fiocruz) for the laboratory support and the supply of the virus from human dengue patient sera; to Dr S Giovanni-De-Simone (Laboratório de Bioquímica de Proteínas e Peptídeos, Departamento de Bioquímica e Biologia Molecular, IOC-Fiocruz) for laboratory support to perform electrophoresis and immunoblotting analyses and Dr José Antonio P Sá Ferreira for the critical review of the manuscript.

\section{REFERENCES}

Biedryzcka A, Canchi MR, Bartholomeusz A, Gorman JJ, Wright PJ 1987. Characterization of proteose cleavage sites involved in the formation of the envelope glycoprotein and three non-structural proteins of dengue virus type, New Guinea "C" strain. J Gen Virol 68: 1317-1326.

Chang GJ 1997. Molecular biology of dengue viruses. In DJ Gubler, G Guno (eds), Dengue and Dengue Hemorrhagic Fever, CAB International, London, p. 175-198.

Churdboonchart V, Bhamarapravati N, Peampramprecha S, Sirinavin S 1991. Antibodies against dengue viral proteins in primary and secondary dengue hemorrhagic fever. Am J 
Trop Med Hyg 44: 481-493.

Corner LC, Ng ML 1987. The influence of highter temperature on Dengue-2 virus infected C6/36 mosquito cell line. Can J Microbiol 33: 863-869.

Gubler DJ, Kuno G, Sather GE, Velez M, Oliver A 1984. Mosquito cell cultures and specific monoclonal antibodies in surveillance for dengue viruses. Am J Trop Med Hyg 33: 158-165.

Guzman MG, Kouri GP, Bravo J, Calunga M, Soler M, Vazquez S, Venereo C 1984. Dengue haemorrhagic fever in Cuba. I. Serological confirmation of clinical diagnosis. Trans $R$ Soc Trop Med Hyg 78: 235-238.

Heinz, FX, Collett MS, PurcellRH, Gould EA, Howard CR, Houghton M, Moormann RJ, Rice CM, Thiel HJ 2000. Family Flaviviridae. In Virus Taxonomy. Seventh Report of the International Committee on Taxonomy of Virus. Edited by MHV Van Regenmortel CM, Fauquet DHL, Bishop EB, Cartens MK, SM Lemon, J Maniloff MA, Mayo DJ NcGeoch, CRPringle, RB Wikner, AcademicPress, San Diego, p. 859-878.

Igarashi A 1978. Isolation of a Singh's Aedes albopictus cell clone sensitive to dengue and chikungunya viruses. $J$ Gen Virol 40: 531-544.

Kuno G, Vorndam AV, Gubler DJ, Gomez I 1990. Study of antidengue NS1 antibody by Western blot. J Med Virol 32: 102108.

Laemmli UK 1970. Clevage of structural proteins during the assembly of the head of bacteriophage T4. Nature 227: 680-685.

Miagostovich MP, Nogueira RMR, dos Santos FB, Schatzmayr HG, Araujo ESM, Vorndam V 1999. Evaluation of an IgG enzyme-linked immunosorbent assay for dengue diagnosis. J Clin Virol 14: 183-189.

Nogueira RMR, Miagostovich MP, Filippis AMB, Pereira MAS, Schatzmayr HG 2001. Dengue virus type 3 in Rio de Janeiro, Brazil. Mem Inst Oswaldo Cruz 96: 925-926.

Rice CM, Lenches EM, Eddy SR, Shin SJ, Sheets RL, Strauss
JH 1985. Nucleotide sequence of yellow fever virus: implications for flavivirus gene expression and evolution. Science 229: $726-733$.

Se-Thoe SY, Ng MML, Ling AE 1999. Retrospective study of western blot profiles in immune sera of natural dengue virus infections. J Med Virol 57: 322-330.

Shu PY, Chen LK, Chang SF, Yueh YY, Chow L, Chien LJ, Chin C, Lin TH, Huang JH 2000. Dengue NS1-specific antibody responses: isotype distribution and serotyping in patients with dengue fever and dengue hemorrhagic fever. $J$ Med Virol 62: 224-232.

Smith TJ, Brandt WE, Swansen JL, McCown JM, Buescher EL 1970. Physical and biological properties of dengue-2 virus and associated antigens. J Virol 5: 524-532.

Svitkin YV, Lyapustin VN, Lashkevich VA, Agol VI 1984. Differences between translation products of tick-borne encephalitis virus RNA in cell-free system from Krebs-2 cells and rabbit reticulocytes: involvement of membranes in the processing of nascent precursors of flavivirus structural proteins. Virology 135: 536-541.

Towbin H, Staehelin T, Gordon J 1979. Electrophoretic transfer of proteins from polyacrylamide gels to nitrocellulose sheets: procedure and some applications. Proc Nat Acad Sci 76: 4350-4354

Valdés K, Alvarez M, Pupo M, Vazquez S, Rodriguez R, Guzman MG 2000. Human dengue antibodies against structural and nonstructural proteins. Clin Diagn Lab Immunol 7: 856-857.

WHO-World Health Organization 1986. Dengue Haemorrhagic Fever: Diagnosis, Treatment and Control, Geneva, p. 59.

WHO-World Health Organization 1997. Dengue Haemorrhagic Fever: Diagnosis, Treatment and Control, Geneva, p. 1223.

Wright PJ, Westaway EG 1977. Comparisons of the peptide maps of Kunjin virus proteins smaller than the envelope protein. J Virol 24: 662-672. 